\title{
Efficacy of probiotics in the prevention of diarrhea in ventilated critically ill ICU patients: meta-analysis of randomized control trials
}

\author{
Kentaro Shimizu* (D), Tomoya Hirose and Hiroshi Ogura
}

\begin{abstract}
We comment on the study by Batra et al. on the efficacy of probiotics in the prevention of ventilator-associated pneumonia in critically ill ICU patients. They also reported that probiotics administration was not associated with a statistically significant reduction in the incidence of diarrhea (OR 0.59; $\mathrm{Cl} 0.34,1.03 ; P=0.06 ; P^{2}=38 \%$ ). However, their meta-analysis missed one RCT, and when we repeated the analysis including this RCT, we found that probiotics administration significantly reduced the incidence of diarrhea (OR 0.51; $\left.\mathrm{Cl} 0.28,0.92 ; P=0.02 ; P^{2}=45.6 \%\right)$. We thus believe that probiotics administration is effective in reducing the incidence of diarrhea in ventilated critically ill ICU patients.
\end{abstract}

Keywords: Intensive care, Enteritis, Stool, Diarrhea, Probiotics, Mechanical ventilators, Critical care

\section{Dear Editor,}

We read with interest the recently published article 'Efficacy of probiotics in the prevention of VAP in critically ill intensive care unit (ICU) patients: an updated systematic review and meta-analysis of randomized control trials' by Batra et al. [1] They showed that the administration of probiotics reduced the incidence of ventilatorassociated pneumonia (VAP), the duration of mechanical ventilation, length of ICU stay, and in-hospital mortality, but that it was not associated with a statistically significant reduction in the incidence of diarrhea (odds ratio [OR] 0.59; confidence interval [CI] 0.34, 1.03; $P=0.06$; $\left.I^{2}=38 \%\right)$.

Probiotics are live non-pathogenic microbes that reduce bacterial translocation by activating mucosal immunity. Probiotics increase short-chain fatty acids and suppress systemic inflammatory response by stabilizing

*Correspondence: shimiken@hp-emerg.med.osaka-u.ac.jp

Department of Traumatology and Acute Critical Medicine, Osaka University Graduate School of Medicine, 2-15 Yamadaoka, Suita, Osaka 565-0871, Japan the gut microbiota [2]. The immune system's T cells and $B$ cells are influenced by the microbiota and could be related to immune-related and miscellaneous diseases [3]. This mechanism might indicate the importance of maintaining the gut microbiota by probiotics to help suppress VAP. Therefore, it is presumed that the incidence of diarrhea would also decrease. In our past propensity study, probiotics reduced the incidence of both diarrhea and VAP [4].

We scrutinized the nine randomized controlled trial papers examined in the Batra et al. review article and identified an issue. The incidence of diarrhea of Shimizu et al. [5] was not included in the meta-analysis by Batra et al. [1]. In that paper, enteritis was defined as the acute onset of continuous liquid stools for more than $12 \mathrm{~h}$. The incidence of enteritis was significantly lower in the probiotics administration group than that in the control group (6.3\% vs. $27.0 \% ; P<0.05)$.

Therefore, we reassessed the meta-analysis by adding the Shimizu et al. paper [5] to the four papers included in the Batra et al. paper that examined diarrhea. As a result, five studies reported diarrhea in 526 patients (264 original author(s) and the source, provide a link to the Creative Commons licence, and indicate if changes were made. The images or other third party material in this article are included in the article's Creative Commons licence, unless indicated otherwise in a credit line to the material. If material is not included in the article's Creative Commons licence and your intended use is not permitted by statutory regulation or exceeds the permitted use, you will need to obtain permission directly from the copyright holder. To view a copy of this licence, visit http://creativecommons.org/licenses/by/4.0/. The Creative Commons Public Domain Dedication waiver (http://creativeco mmons.org/publicdomain/zero/1.0/) applies to the data made available in this article, unless otherwise stated in a credit line to the data. 


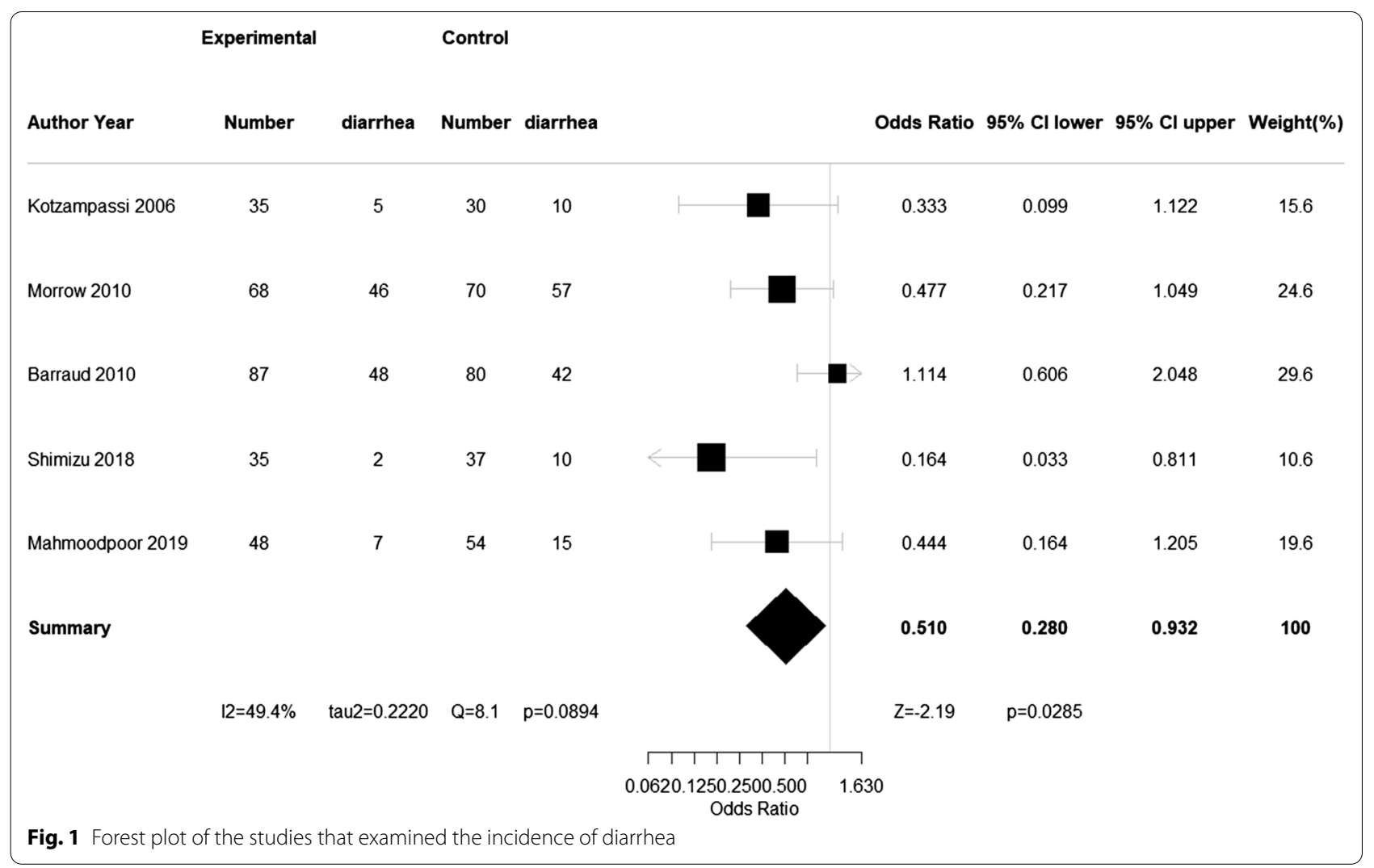

in the probiotic arm and 262 in the placebo arm). We found that the administration of probiotics significantly reduced the incidence of diarrhea (OR 0.51; CI 0.28, 0.92; $\left.P=0.02 ; I^{2}=45.6 \%\right)$, as shown in the Fig. 1 .

This result indicated an effect of probiotics on reducing diarrhea in ventilator-treated patients. Probiotics have been reported to reduce infectious complications related to postoperative complications [6] and trauma [7] and to reduce Clostridium difficile infection induced by antibiotics [8]. The mechanism is thought to be maintenance of immunity by stabilizing the gut microbiota. Patients who require mechanical ventilation are also at high risk of deterioration of their intestinal bacterial flora due to critical illness such as sepsis and the administration of antibiotics [9], which could induce diarrhea and VAP. In fact, the administration of probiotics for such conditions induced significant production of acetic acid, a metabolite of total obligate anaerobes and gut microbiota [2]. It is reasonable that the maintenance of the gut microbiota not only reduces VAP, but also contributes to a reduction of diarrhea. We thus believe that the administration of probiotics is effective in reducing the incidence of diarrhea in ventilated critically ill ICU patients.

\section{Abbreviations}

Cl: Confidence interval; ICU: Intensive care unit; OR: Odds ratio; VAP: Ventilatorassociated pneumonia.

\section{Acknowledgements}

Not applicable.

Authors' contributions

$\mathrm{KS}$ and TH performed the analysis and wrote the manuscript. HO corrected the manuscript. All authors read and approved the final manuscript.

\section{Funding}

The study was supported by the Japan Society for the Promotion of Science (JSPS) KAKENHI Grant Number 19H03761.

\section{Availability of data and materials}

Not applicable.

\section{Declarations}

Ethics approval and consent to participate

Not applicable.

\section{Consent for publication}

Not applicable.

\section{Competing interests}

The authors declare that they have no competing interests.

Received: 16 April 2021 Accepted: 9 August 2021

Published online: 15 October 2021 


\section{References}

1. Batra P, Soni KD, Mathur P. Efficacy of probiotics in the prevention of VAP in critically ill ICU patients: an updated systematic review and metaanalysis of randomized control trials. J Intensive Care. 2020;8:81.

2. Shimizu K, Ogura H, Goto M, Asahara T, Nomoto K, Morotomi M, et al. Synbiotics decrease the incidence of septic complications in patients with severe SIRS: a preliminary report. Dig Dis Sci. 2009;54(5):1071-8.

3. Honda K, Littman DR. The microbiota in adaptive immune homeostasis and disease. Nature. 2016;535(7610):75-84.

4. Shimizu K, Ogura H, Kabata D, Shintani A, Tasaki O, Ojima M, et al. Association of prophylactic synbiotics with reduction in diarrhea and pneumonia in mechanically ventilated critically ill patients: a propensity score analysis. J Infect Chemother. 2018;24(10):795-801.

5. Shimizu K, Yamada T, Ogura H, Mohri T, Kiguchi T, Fujimi S, et al. Synbiotics modulate gut microbiota and reduce enteritis and ventilator-associated pneumonia in patients with sepsis: a randomized controlled trial. Crit Care. 2018;22(1):239.

6. Wu XD, Liu MM, Liang X, Hu N, Huang W. Effects of perioperative supplementation with pro-/synbiotics on clinical outcomes in surgical patients: a meta-analysis with trial sequential analysis of randomized controlled trials. Clin Nutr. 2018;37(2):505-15.

7. Gu WJ, Deng T, Gong YZ, Jing R, Liu JC. The effects of probiotics in early enteral nutrition on the outcomes of trauma: a meta-analysis of randomized controlled trials. JPEN J Parenter Enteral Nutr. 2013;37(3):310-7.

8. Goldenberg JZ, Mertz D, Johnston BC. Probiotics to prevent Clostridium difficile infection in patients receiving antibiotics. JAMA. 2018;320(5):499-500

9. Ojima M, Shimizu K, Motooka D, Ishihara T, Nakamura S, Shintani A et al. Gut dysbiosis associated with antibiotics and disease severity and its relation to mortality in critically III patients. Dig Dis Sci. 2021;1-13. https://doi. org/10.1007/s10620-021-07000-7.

\section{Publisher's Note}

Springer Nature remains neutral with regard to jurisdictional claims in published maps and institutional affiliations.
Ready to submit your research? Choose BMC and benefit from:

- fast, convenient online submission

- thorough peer review by experienced researchers in your field

- rapid publication on acceptance

- support for research data, including large and complex data types

- gold Open Access which fosters wider collaboration and increased citations

- maximum visibility for your research: over $100 \mathrm{M}$ website views per year

At $\mathrm{BMC}$, research is always in progress.

Learn more biomedcentral.com/submissions 